\title{
AOR
}

Selected Papers of \#AolR2019:

The $20^{\text {th }}$ Annual Conference of the Association of Internet Researchers Brisbane, Australia / 2-5 October 2019

\section{'FASCISM IS THE NEW HIP': ONLINE ANTI-PUBLICS AND POST- NORMATIVE DEMOCRACY}

Mark Davis

University of Melbourne

In the past decade there has been a notable convergence across the far-right political spectrum. Groups known for their white supremacist ideology have been talking about climate science. Groups that seek to promote 'men's rights' have joined forces with white supremacist groups under the banner of the alt right. Some sections of the alt right have taken up the anti-vaccination cause. Such groups, I argue, can be understood as belonging to a loose-knit, diverse online 'anti-public sphere', populated by overlapping 'anti-publics' such as the 'alt-right', white supremacist groups, 'men's rights' groups, anti-climate science groups, and 'neoreactionary' or 'Dark Enlightenment' groups, among others. This is a heterogenous space of often fractious social interaction where discourse routinely flouts traditional democratic norms, such as normative 'public sphere' conventions of rational-critical deliberation, rules of evidence and argumentation, and requirements for truthfulness, reciprocity, mutuality, and so on, over and above the ways in which democratic debate is properly passionate (Papacharissi, 2016) or agonistic (Mouffe, 2013), in order to advance its ideological causes.

The paper will build on earlier theorisations of anti-publics by McKenzie Wark (1997) and Bart Cammaerts (2007). Wark identifies the emergence of the US citizen militia movement and the Waco, Texas siege of 1993 as a key symbolic moment in the development of anti-publics that he argues arose as a product of a Habermasian 'legitimation crisis' whereby significant numbers of people had lost faith in democratic processes. According to Cammaerts neo-Nazi and fundamentalist movements and 'negationism, (verbal) gay bashing, blatant racism, promotion of hatred, violence and other essentialisms' (2007: 87), are examples of anti-publics 'going against the basic values of democratic culture' (2007: 74). Such anti-publics, according to Cammaerts, are 'counter-hegemonic' (2007: 73) in that not only are they detached from the dominant public sphere but because they actively oppose basic democratic norms and institutions. This is now true, I argue, not only of far-right militia groups in the US and hate groups in Europe, but of a much wider array of groups that explicitly seek to destabilise and undermine democratic standards and conventions. 
Online anti-publics, I will argue, pose a different order of challenge to publicity than counterpublics (Fraser, 1992; Negt and Kluge, 1993), since rather than demand democratic reform or inclusion they attack the very conditions of democratic possibility, including the trust networks that underpin such possibility, as outlined in the conference themes. Nor are anti-publics agonistic in the sense that, as Chantal Mouffe (2013) has argued, democratic practice is often rightly fractious. Rather, they are antagonistic and understand politics as a battle to be won at any cost, using means such as disinformation campaigns, standover and bullying tactics such as organised trolling and doxxing, and in some cases physical violence, to achieve their ends.

While routinely dismissed as aberrant and extreme, the growing influence of online antipublics reflects developments in mainstream political discourse that include the mainstreaming of right-wing populism and anti-other and anti-elite sentiment, as were made manifest in the 2016 \#Brexit vote and in the role played by far-right groups in supporting the election in 2016 of Donald Trump as US president. Such developments, along with the rise of far-right politics across Europe and the return of 'strongman' politics in the international arena, belong to a broader transition towards what I call 'post-normative democracy' whereby traditional democratic systems and norms have become deeply compromised. This includes the normalisation of race politics across the west via attacks on groups such as immigrants, indigenes and refugees, attacks on human rights conventions, the normalisation of differential regimes of global citizenship (Ong, 2006), attempts to undermine legal processes, attacks on the media and journalists, attempts to shore up subvert gains made by marginalised groups such as women and LGBTQI+ people, and systematic attempts to undermine trust in institutions, as seen, for example, in the systematic promotion of disinformation about climate science. The connection between this post-normative politics and anti-publics prompts urgent research. The paper will show how anti-publics play a role in fomenting postnormative democratic politics amidst growing fears about creeping authoritarianism and neo-Fascism, and how to advance this cause far right groups have sought to appropriate the mantles of iconoclasm and subcultural 'cool' from the left, as evidenced in claims such as that made by white supremacist Andrew Anglin (2015) that 'fascism is the new hip'.

To make its case the paper will take a qualitative approach based in five brief case studies. Examples are given of anti-public discourse used by white supremacist groups, 'men's rights' groups, anti-climate science groups, neoreactionary groups, and extreme anti-vaccination groups, to demonstrate close similarities in their discourse. Through close reading and discourse analysis the paper will demonstrate how anti-public discourse often takes an approach based in the privileging of first-person experience over expert knowledge, in attacks on Others and 'elites', and in the valorization of essentialist understandings of race, gender, and ability, as a basis for social ordering.

The paper will also briefly consider the historical background for the growing influence of anti-publics and emergence of post-normative democracy that include a background of economic failure and collapsing social contracts, growing inequality, declining public trust in institutions, advancing 'democratic decay' (Daly, 2018) and a growing sense that liberal democracy has failed (Fenton, 2018). Developments in the media that have played a role include the disintermediation of traditional forms of media gatekeeping and 
the new digital hegemony of algorithmic gatekeepers (Daniels, 2018), the surplus of information, its lack of verifiability, and proliferation of conspiracy logics (Andrejevic, 2013), and the development since the 1960s of a right wing media sphere with its own codes, values and ways of knowing, that stretches from televangelism to Fox News, from outlets such as Breitbart News, to bulletin boards such as 4chan.

\section{References}

Andrejevic M (2013) Infoglut: How Too Much Information Is Changing the Way We Think and Know. New York: Routledge.

Anglin A (2015) Anonymous cuckolds attack virtually non-existent KKK, media celebrates. In: Daily Stormer. Available at:

http://www. dailystormer.com/anonymous-cuckolds-attack-virtually-non-existentkkk-media-celebrates/ (accessed 14 November 2016).

Cammaerts B (2007) Jamming the political: beyond counter-hegemonic practices. Continuum: Journal of Media \& Cultural Studies 21(1): 71-90.

Daly TG (2018) Searching for Democracy 2.0 without losing Democracy 1.0. Available at: https://pursuit.unimelb.edu.au/articles/searching-for-democracy-2-0-withoutlosing-democracy-1-0 (accessed 21 January 2019).

Daniels J (2018) The Algorithmic Rise of the "Alt-Right". Contexts 17(1): 60-65.

Fenton N (2018) Fake democracy: the limits of public sphere theory. Javnost - The Public 0(0): 1-7. DOI: 10.1080/13183222.2018.1418821.

Fraser N (1992) Rethinking the public sphere: a contribution to the critique of actual existing democracy. In: Calhoun C (ed.) Habermas and the Public Sphere. Cambridge, MA: MIT Press, pp. 109-142.

Mouffe C (2013) Agonistics: Thinking the World Politically. London and New York: Verso.

Negt O and Kluge A (1993) Public Sphere and Experience: Analysis of the Bourgeois and Proletarian Public Sphere. Minneapolis: University of Minnesota Press.

Ong A (2006) Neoliberalism as Exception: Mutations in Citizenship and Sovereignty. Durham, N.C: Duke University Press.

Papacharissi Z (2016) Affective publics and structures of storytelling: sentiment, events and mediality. Information, Communication \& Society 19(3): 307-324.

Wark M (1997) Black thunder. In: Bayliss S and Holt S (eds) Transit Lounge. Sydney: Craftsman House, pp. 180-184. 